\title{
The essential role of democracy in the Bush Doctrine: the invasions of Iraq and Afghanistan ${ }^{1}$
}

\author{
O papel essencial da democracia na Doutrina Bush: \\ as invasões do Iraque e do Afeganistão
}

MARIA HELENA DE CASTRO SANTOS* ULYSSES TAVARES TEIXEIRA**

Rev. Bras. Polit. Int. 56 (2): 131-156 [2013]

\section{Introduction}

Everyone knows that democracy played a role in the Bush Doctrine. What not everyone knows is that this role was essential for the doctrine to be put into operation under which the Iraq invasion was prepared and launched. Preemptive war was the rocket, democracy was the fuel, terrorism was the target. This is the main argument of this article.

In fact, George W. Bush was the president of the post-Cold War era who very explicitly made use of the most radical means of exporting democracy-the use of force. He did so by placing the exporting of democracy into the core of his National Defense Policy and by making of it a fundamental pillar of his foreign policy after September 11.

There were other American military interventions since the end of the Cold War, but in none of them the exporting of democracy to the target country assumed

\footnotetext{
1 This article contains partial results of a broader research project titled The Exporting of Democracy in the American Foreign Policy in the Post-Cold War Period: Doctrines, Ideas and the Use of Force. Another research product was published in Revista Brasileira de Politica Internacional, 53(1), 157-191, 2010, under the title Exportação de Democracia na Politica Externa Norte-Americana no Pós-Guerra Fria: Doutrinas e o Uso da Força. The most efficient research assistantship of Fernanda Freitas, Isabella Guimarães and Rodrigo Fonseca are acknowledged. The support of the National Research Council (CNPq) by means of undergraduate and senior researcher fellowships was essential to the completion of this article. CAPES also contributed to the research development with a doctoral fellowship. Earlier versions of this paper were presented to the $53^{\text {rd }}$ Annual Convention of the International Studies Association (ISA), San Diego, April 2012 and to the $36^{\text {th }}$ Meeting of the National Association for Research and Graduate Studies (ANPOCS), Águas de Lindoia, São Paulo, October 21-25, 2012.

* Maria Helena de Castro Santos is Associate Professor at the Instituto de Relaçôes Internacionais (IREL) at University of Brasília (UnB), Brasília, Brazil (mhelena@unb.br).

** Ulysses Tavares Teixeira is a PhD student at Instituto de Relações Internacionais (IREL) at the University of Brasília (UnB), Brasília, Brazil (ulyssestteixeira@gmail.com).
} 
such a prominent role. ${ }^{2}$ This is because democracy was identified by the Bush Administration as the ultimate weapon to win the War on Terror.

By means of quantitative and qualitative content analysis of 391 speeches of President George W. Bush, Secretaries of State Colin Powell and Condoleezza Rice and Secretaries of Defense Donald Rumsfeld and Robert Gates, we will better qualify the above assertions. In fact, among the motivations and justifications for the invasions of Afghanistan and Iraq, bringing democracy to those societies, an objective presented in the communications of the decision-makers since the early hours after September 11, would take prominence over security reasons only in the second Bush Administration.

We will argue moreover that even an aggressive doctrine like Bush's is surely compatible with the American Liberal Tradition (Hartz 1955), as expressed in the principles that constitute the pillars of the foreign policy doctrines of all the American post-Cold War presidents. ${ }^{3}$

The first section will examine the links between democracy and security in the pillars of the American foreign policy doctrine in the post-Cold War era as well as the relative emphasis the Bush Administration puts on the tenets of this policy doctrine.

The second section will analyze the Bush Defense Doctrine, identifying its radical neoconservative basis - the unilateral preemptive war-and the links with the exporting of democracy. It will be shown as well that both the foreign and the defense policies are rooted in the American Liberal Tradition.

Finally, the third section will bring the analysis of the motives and justifications for the military interventions in Afghanistan and Iraq displayed by Bush and his Secretaries of State and Defense in their speeches. The aim in this section is to evaluate the proportion of justifications based on purely security reasons as compared to those that bond democracy building in the target countries to American security.

\section{The pillars of the American foreign policy doctrines in the post-Cold War period}

This section will present the basic pillars of the American foreign policy doctrine in the post-Cold War period and how the Bush Administration made use of them. The objective here is to identify how the links between security, democracy and liberalism were defined in the President's administration and

2 In a previous work we analyzed the role of democracy fulfilled in the American military interventions in the post-Cold War period: Somalia, Bosnia, Kosovo, Afghanistan, and Iraq. See Castro Santos, M. H. and Teixeira, U. T., Exporting Democracy as Foreign Policy: Peace, Security and the American Military Interventions in the Post-Cold War World. Paper presented at the Third World International Studies Conference (WISC), Porto, August 17-20, 2011.

3 Those principles were empirically identified by Castro Santos (2010a). We will refer to them in the third section of this article. 
influenced his foreign and defense policies. This will help understand the military invasions in the Middle East.

\section{Liberalism and American exceptionalism ${ }^{4}$}

There is a well-established tradition of thinking about US foreign policy in terms of American exceptionalism (see Tocqueville 1835; Hofstadter 1948; Boorstin 1953; Hartz 1955; Packenham 1973; Lipset 1996). This is an expression referred to the unique political and economic conditions under which the American processes of state-building and nation-building developed, and the ways they affected its constitutional structures and its decision-making (Buzan 2004, 154-163). As the first colony to become independent, America "has defined its raison d'être ideologically" (Lipset 1996, 18). Richard Hofstader noted that "It has been our fate as a nation not to have ideologies, but to be one" (apud Lipset 1996, 18). This ideology, also called American political religion, American Creed, or American Liberal tradition, can be described in five terms: liberty, egalitarianism, individualism, populism, and laissez-faire (Lipset 1996, 19). These are the premises that shape the American political structures, decision-making, and world view; it is their uniqueness that makes America exceptional.

Analyzing the liberal facet of American foreign policy, Buzan (2004, 155-157) concludes that

it is also in the grip of a belief that liberal values are universal, and that the intrinsic moral and practical superiority of liberal values gives them the right to claim the future of mankind. As Patrick $(2002,7)$ observes, 'the validity of the country's liberal principles derives from their presumed universality' and underpins a missionary element in US foreign policy.

These elements, the universality of the liberal values and the mission to spread freedom around the world are clearly represented in the pillars of the foreign policy doctrine in the post-Cold War period.

The pillars of the American foreign policy doctrine in the post-Cold War era

Based on Packenham (1973) and in Hartz (1955), Castro Santos (2010a) identified the basic pillars of the American foreign policy doctrine in the post-Cold War era, linking them to the American liberal tradition.

The fall of Soviet communism and the end of the Cold War signaled a strong shift in the world order. After four decades of bipolar disputes, the American victory was interpreted as the proof of the superiority of the American way of life. The hypotheses of exceptionalism seemed to be right. According to Farer (1996), one

4 Teixeira (2010) provides a thorough analysis of American exceptionalism. 
of the greatest advantages of this moment was the opportunity for America, in the absence of visible threats, to coherently base its foreign policy doctrine on the liberal principles, without having to incur in the Cold War ambiguities between values and interests.

In fact, if the liberal values shaped the American thought related to political development during the Cold War (Packenham 1973), now they manifest themselves in a different set of principles related to democracy promotion in foreign policy. In the post-Cold War, the liberal ideas will face the challenges of humanitarian assistance, the use of force, the role of the United States in the world, regional stability, defense doctrines and world peace. Debates will be pervasive, but at the end these elements will all combine to share the same ideological tenets of the liberal tradition.

Using quantitative and qualitative content analysis of 415 speeches of the first three post-Cold War Presidents and their Secretaries of State, Castro Santos (2010a) identified the pillars of American foreign policy doctrines that justify the exporting of democracy even if by the use of force-the most difficult means to be employed in the name of democracy. When the 240 speeches of the Secretaries of Defense were included in the analysis, the pillars formerly identified were confirmed. ${ }^{5}$ Three principles and one American mission, so to speak, were recurrent in the speeches analyzed, constituting the pillars of the American foreign policy in the post-Cold War period:

1. The values and principles of the Western liberal democracy are universal, that is, all the peoples of the world wish to become democratic. Democracy is not culturally bound. Therefore, the promotion of democracy is for the good of mankind.

2. Democracies do not fight each other. Therefore, exporting democracy means to promote regional and even global peace. Here democracy is linked to regional and global security.

3. The promotion of democracy makes the world safer and more prosperous for the United States. Here democracy is linked to the security and the economic interests of the United States.

Mission: the Americans think of themselves as having a mission to bring freedom and democracy to mankind.

5 From Presidents George H. W. Bush, Bill Clinton, and George W. Bush, we analyzed all the speeches from the following categories: State of the Union, Inaugural Addresses, Addresses to Congress, Major Addresses to the Nation and the Bush Doctrine main speeches. They were all taken from the American Presidency ProjectUniversity of California, Santa Barbara (<http://www.presidency.ucsb.edu/>). From the Secretaries of State we collected the speeches made at the UN, NATO and the US Congress, available since 1993. Source: US Department of State (<http://www.state.gov>). From the Secretaries of Defense we analyzed all their speeches as reproduced in the US Department of Defense website, available since 1995 (<http://www.defense.gov >). To avoid selection biases, we opted to analyze all the speeches in each category, and not just foreign-policy-, democracy-, or warrelated communications. 
Principle one and the American mission are deeply embedded in liberal values. Wrapped up by the Kantian peace, principle two links liberal values to peace and security. The third principle associates liberal ideological values to American national interests. It is a crucial tenet of the American foreign policy doctrine in the post-Cold War era.

Finally it is important to say that, even if all administrations of the post-Cold War period made constant use of the three principles and the American mission here identified, each administration put different emphasis on the principles or mission, according to the way the President and his foreign policy team saw the role of the United States ${ }^{6}$ in the new international order and the external challenges they had do face. ${ }^{7}$

\section{The choices of the Bush Administration}

After September 11 the Bush Administration started to define American security in terms of its capacity to influence regime change in rogue states. The exporting of democracy was brought to the status of defining principle of the foreign policy doctrine, becoming an important part of the American response to the terrorist threat.

In fact, we can say that in the Bush Administration the third principle of American foreign policy doctrine, as identified above, was crucial to justify the military invasions of Afghanistan and Iraq. It assumed that the US and the world would only be truly safe when rogue states became democratic. This is because the President and his Secretaries of State and Defense thought that, in the long run, the major weapon to fight terrorism was democracy. The reason was that it was assumed that authoritarian states harbored terrorists, and produced and distributed to them weapons of mass destruction (WMDs).

When we take the two Bush Administrations separately, we will see that although the importance of the here called third principle was unequivocal in Bush's second term in office, this was not true during his first government. In fact, the quantitative content analysis of 391 speeches of the President and his Secretaries of State and Defense showed that references to the links between the building of democracy in rogue states and American security were present in 39\% of those communications in the second period of Bush in office, while this proportion reached only $11 \%$ in his first administration (Table 1 ).

6 For a brief analysis of the role of the United States in the post-Cold War period as seen by the different Presidents, see Castro Santos (2010c).

7 The relative emphasis the post-Cold War administrations put on the pillars of the foreign policy doctrines is analyzed in further detail in Castro Santos (2010a). 
Table 1. The relative use of the pillars of the American foreign policy in the Bush Administration. ${ }^{(1)}$

\begin{tabular}{|l|c|c|c|c|c|}
\hline \multicolumn{1}{|c|}{ Principles } & $\mathbf{1}^{\text {st }}$ & $2^{\text {nd }}$ & $3^{\text {rd }}$ & $\begin{array}{c}\text { The American } \\
\text { Mission }\end{array}$ & $\begin{array}{c}\text { Total number of } \\
\text { speeches }\end{array}$ \\
\hline Bush's first term & 35 & 17 & 27 & 55 & 253 \\
Bush's second term & 29 & 39 & 54 & 7 & 138 \\
\hline Total & 64 & 56 & 81 & 62 & 391 \\
\hline
\end{tabular}

(1) The numbers in the cells represent the number of speeches that contain references to each principle or mission. Even if a principle or the American mission is referred to more than once in the same speech we registered only one occurrence per speech of the principle or mission.

Source: analysis of 391 selected speeches of President Bush and his Secretaries of State, Powell and Rice, and Secretaries of Defense, Rumsfeld and Gates, 2001-2008.

In fact, in 2001 and 2002, the years of the preparation for the Iraq invasion, the altruistic pillars of the American foreign policy doctrine-the American mission to bring freedom to all the peoples in the world and the universality of the democratic values - were relatively more emphasized in the 107 decision-makers speeches analyzed, reaching, respectively, $22 \%$ and $14 \%$ (Figure 1 ). The appeal was to the American liberal tradition, deeply embedded in each American soul, as a heritage of their exceptional and happy history translated into the legacy of the founding fathers. ${ }^{8}$

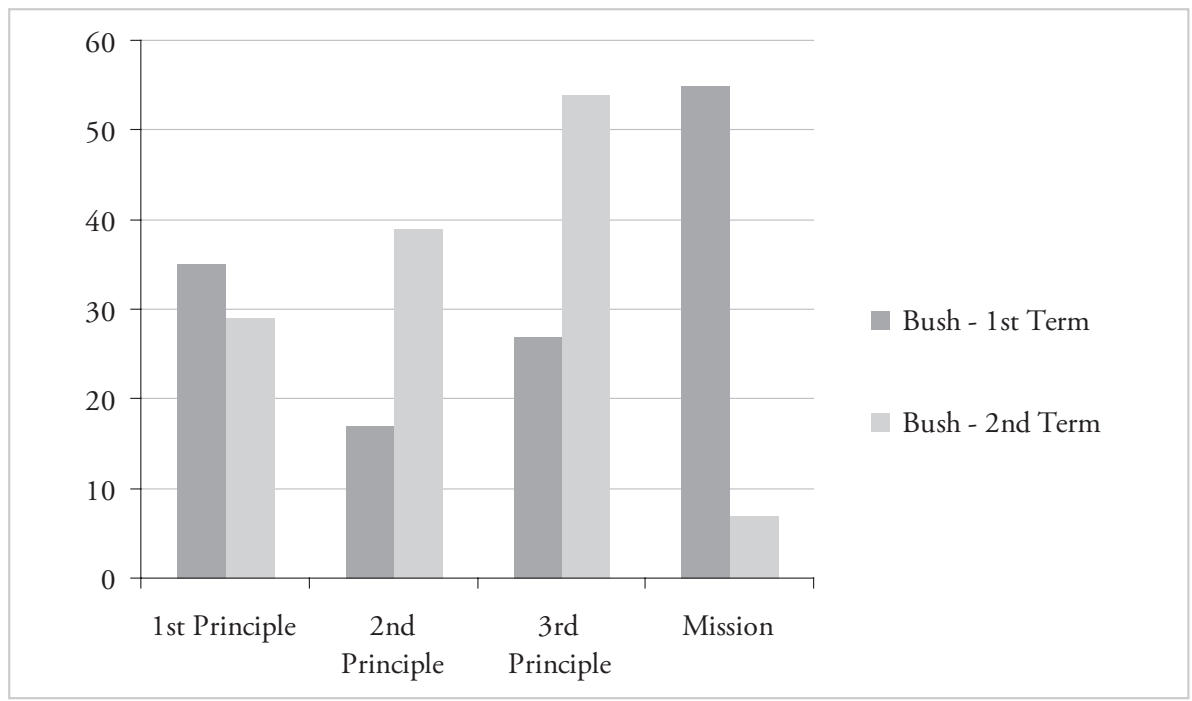

Figure 1. The relative use of the pillars of the American foreign policy per Bush Administration.

Source: 391 selected speeches of President Bush and his Secretaries of State, Powell and Rice, and Secretaries of Defense, Rumsfeld and Gates, 2001-2008.

8 See Packenham (1973) for his analysis of the "layers of liberalism" displayed by Americans. 
The other altruistic pillar, the here called second principle, establishes that democracies are less prone to engage in war against each other. Bush and his secretaries were sure that a democratic Iraq would spread democracy to the Middle East. This means that, according to this principle, the democratization of Iraq included the promise of regional and world peace. Based on the so-called Kantian peace, this pillar of the foreign policy doctrine received less emphasis than the other principles and mission: around 5\% of the 107 speeches selected in 2001 and 2002 mentioned it at least one time (Table 2). But it still completed the array of good values upon which the military actions were justified.

Table 2. The relative use of the pillars of the American foreign policy in the Bush Administration, per year.

\begin{tabular}{|c|c|c|c|c|c|}
\hline Year & $\mathbf{1}^{\text {st }}$ Principle & $2^{\text {nd }}$ Principle & $3^{\text {rd }}$ Principle & Mission & $\begin{array}{c}\text { Total number of } \\
\text { speeches analyzed }\end{array}$ \\
\hline 2001 & 8 & 4 & 3 & 14 & 54 \\
2002 & 5 & 2 & 5 & 15 & 53 \\
2003 & 7 & 9 & 10 & 11 & 84 \\
2004 & 15 & 2 & 9 & 15 & 62 \\
2005 & 19 & 18 & 15 & 4 & 51 \\
2006 & 10 & 10 & 20 & 1 & 42 \\
2007 & 3 & 10 & 10 & 1 & 32 \\
2008 & 2 & 1 & 9 & 1 & 13 \\
\hline Total & 69 & 56 & 81 & 62 & 391 \\
\hline
\end{tabular}

Source: analysis of 391 selected speeches of President Bush and his Secretaries of State, Powell and Rice, and Secretaries of Defense, Rumsfeld and Gates, 2001-2008.

Those altruistic pillars, together with the threat of additional terrorist attacks and the assurance by American intelligence of the existence of WMDs in Iraq were efficacious to raise the support of the population to the military invasions in the two Middle East countries. In fact, during the first two years of war, a clear majority backed the decision to use force in Iraq, $72 \%$ and $55 \%$, respectively in 2003 and 2004. Public opinion split almost by half in the third and fourth years of military action, when around $46 \%$ still favored the war and approximately $47 \%$ opposed it. It was only in 2006 that opposition to the use of force in Iraq reached a higher proportion than its support, reaching $54 \%$ in 2008 against the approval of 38\% (cf. the Pew Research Center's national surveys conducted between March 2003 and February 2008).

In March 2003 Iraq was invaded. In May, Bush declared the American victory. By September 2004, however, it became clear that WMDs had not been plotted in Iraq against the United States. In his final report, the CIA's top weapons inspector in Iraq's WMD acknowledged that the hunt for weapons of 
mass destruction had "gone as far as feasible" and that they had found nothing, closing an investigation into the purported programs of Saddam Hussein that were used to justify the 2003 invasion (cf. the Iraq Survey Group Final Report, Volume I, Key Findings, p. 1-5). The Report of the Special Advisor to the Director of Central Intelligence (DCI) reinforced this conclusion (cf. Addendums to the Comprehensive Report of the Special Advisor to the DCI on Iraq's WMD).

The fiasco of the WMDs, besides requiring from the Bush Administration an explanation for such a vexing mistake, ${ }^{9}$ reflected on the change on the relative emphasis given to each principle and mission of the foreign policy doctrine in the following years.

In the beginning of Bush's second term, with no WMDs threat to rely upon as a solid reason to continue the wars in the Middle East, the foreign policy decision-makers reinforced the normative altruistic pillars of the doctrine. Indeed, both the principle of the universality of the democratic values and the principle of the Kantian peace were incorporated, respectively, in $25 \%$ and $30 \%$ of the 125 speeches selected in the years from 2005 to 2007. The exceptions were the references to the mission of the American people, which faded away along the years (cf. Table 2 and also Figure 1).

At the same time, the third and pragmatic principle, which ties democracy to the national interests of the United States, began to scale up. For sure we can identify this principle in the first years after the terrorist attacks. It follows some examples:

Sixty years of Western nations excusing and accommodating the lack of freedom in the Middle East did nothing to make us safe-because in the long run, stability cannot be purchased at the expense of liberty. (George W. Bush, Remarks by the President at the $20^{\text {th }}$ Anniversary of the National Endowment for Democracy, November 6, 2003).

The United States is committed to helping build a stable and democratic Afghanistan that is free from terror and no longer harbors threats to our security... [E]xpanding democracy in the Greater Middle East [is] crucial if we are to attack successfully the motivation to terrorism. (Colin Powell, The President's Budget Request For FY 2005, February 26, 2004).

George W. Bush delivered other speeches stressing the importance of democracy to American security in these first years after September 11 (cf. Addresses to the Nation on Iraq in Ohio, August 10, 2002, and from the USS Abraham Lincoln, May 1 ${ }^{\text {st }}, 2003$; and his Address to the Nation on the Capture of Saddam Hussein, December 14, 2003). So did Colin Powell (see The President's Budget Request For FY 2005, February 26, 2004) and Donald Rumsfeld (Remarks to the Council on Foreign Relations, October 4, 2004).

9 See the fourth section of this paper for this point. 
There is an unequivocal increasing tendency of the number of speeches that refer at least once to the third principle along Bush's period in office. Yet, it is in the second Bush Administration that the proportion of the speeches that called on this principle raised remarkably along the years (cf. Table 2). This is a finding of great relevance. When security by itself went down as a reason for the wars, democratization of the rogue states went up. This is because, by the third principle, democratization is linked to American national interests, there included national security and economic interests. Indeed, it is believed that a more democratic world is safer and more prosperous for the United States. This assertion is necessary to assure that when promoting democracy, the American government is not leaving behind American interests. On this respect Diamond (1994) said, a few years before, that:

Realist thinkers often contend that such tangible national interests conflict with our moral or idealistic interest in democracy and human rights. Certainly we will confront painful tensions and trade-offs. But this view misses the powerful and growing linkages between our moral interest in the expansion of democracy and our 'real' interests in safe, secure, free and prosperous America... Precisely because they respect within their own borders competition, civil liberties, property rights, and the rule of law, democracies are the only reliable foundation on which a new world order of international security and prosperity can be built (pp. 2-3).

Bush and his team engaged in a crusade to reinforce the idea that the United States would be really safe only when rogue states became democratic. At this point, values and interests merged. ${ }^{10}$ Terrorism would only be defeated by democracy. Two examples of their communications follow:

The survival of liberty in our land increasingly depends on the success of liberty in other lands. The best hope for peace in our world is the expansion of freedom in all the world. America's vital interests and our deepest beliefs are now one. (George W. Bush, Inaugural speech to second term, January 20, 2005).

[W]e know that it is not enough to have a short-term solution to terrorism, that is, defeating the terrorists who on a daily basis plot and plan to destroy innocent life, but also to deal $[\ldots]$ with the circumstances that created those terrorists. And we believe that the ideology of hatred which they espouse can only be met by advancing liberty and democracy. (Condoleezza Rice, FY 2007 Budget Request for the Department of State and Foreign Operations, March $28,2006)$.

10 This point was dealt in more detail in Castro Santos and Teixeira (2012). It is a sensitive point that deserves more attention. However, due to the lack of space, we leave it for future communications. It is worth saying here, however, that a great part of the democratization literature and most of the foreign and defense policies' decision-makers do not see values and interests as contradictory. 
Other speeches of the Bush Administration's decision-makers that link democracy building to the American security worth mentioning are: George W. Bush, State of the Union, 2005; Donald Rumsfeld, Town Hall Meeting, Kandahar, Afghanistan, April 13, 2005; George W. Bush, Address to the Nation on the War on Terror, September 11, 2006; Robert Gates, World Forum on the Future of Democracy, September 17, 2007; George W. Bush, Addresses to the Nation on the War on Terror in Iraq, January 10, 2007 and October 13, 2007; George W. Bush, State of the Union, January 2008; Condoleezza Rice, Remarks at the Meeting of the Advisory Committee on Democracy Promotion, October 8, 2008.

In conclusion, we can stress two points. First, the American foreign policy doctrine in the post-Cold War age is deeply rooted in the tenets of liberalism, including Bush's harsh policy. Second, in Bush's foreign policy the here called third principle, which links democracy to security, sticks out. This is true especially in the President's second term in office, when it became clear that there were no WMDs in Iraq. The connection between values and national interests, however, was significantly present in the decision-makers' thought since the first presidential term. This connection will appear as well in the Bush doctrine, playing there a fundamental normative role.

\section{The Bush Doctrine}

When George W. Bush took office as President of the United States in 2001, he and his foreign policy team decided that the liberal multilateral internationalist strategy, which had prevailed in the previous government, was no longer appropriate to represent the international aspirations of the American people. In fact, Bush criticized Clinton for engaging in nation-building and humanitarian interventions overseas. Among his several campaign promises, he stated he would be more selective in relation to the use of force, and called for a less interventionist approach with regard to internal affairs of other countries. His National Security Adviser, Condoleezza Rice (2007), for example, said about the nation-building operation in the Balkans that "carrying out civil administration and police functions is simply going to degrade the American capability to do the things America has to do. We don't need to have the $82^{\text {nd }}$ Airborne escorting kids to kindergarten" (Rice 2007). The defense of the new approach would also become very clear by the words of the President himself: "When it comes to foreign policy, that'll be my guiding question: is it in our nation's interests?" (Presidential Debate in WinstonSalem, North Carolina, October 11, 2000).

Bush was skeptical of multilateralism and unrelenting toward potential adversaries. He refused membership to multilateral agreements such as the International Criminal Court or the Kyoto Protocol. The administration adopted strategic adjustments that focused on supposedly "vital national interests," toward a more realistic foreign policy strategy. 
Inside the government, there were certainly different understandings of which role the United States should play in the post-Cold War international system. The press talked about divergences between the State Department and the Pentagon (cf. Patrick 2001). The well-known neoconservative movement was strongly represented in the administration. But they were not able to influence the foreign policy doctrine toward their preferences in the first months of government. Other presidential advisers, who would not fall in the neoconservative category—such as Collin Powell and Condoleezza Rice—, were openly against idealistic campaigns in foreign policy issues. At this point, the President showed little interest in the radical and aggressive neoconservative political agenda, which included the exporting of democracy by the use of force.

Every debate and criticism ceased, however, on the day of the terrorist attacks against New York and Washington. From that point on, American foreign policy would change its world view. After a dramatic review of his grand strategy, Bush decided to adopt the neoconservative vision embracing a far-reaching and proactive foreign policy based on American military power. The American military interventions in Afghanistan (2001) and Iraq (2003) are the principal manifestations of this new strategy which became known as the Bush Doctrine.

This security strategy represented a radical change in the President's initial world view. Synthesized in the 2002 National Security Strategy (NSS)'s foreword, it proposed that America should "defend the peace by fighting terrorists and tyrants..., preserve the peace by building good relations among the great powers..., [and] extend the peace by encouraging free and open societies on every continent." The NSS, together with seven of Bush's speeches, pronounced in the period of time between the terrorist attacks and the eve of the Iraq invasion, are considered to form the cornerstone of the Bush doctrine. ${ }^{11}$

Bush's first novelty was to identify terrorists, tyrants and the connection between them as the new threats. The victory in the Cold War dazzled American leaders, who did not properly analyze the threats posed by this new type of enemy. Their typical weapons- terrorist attacks and WMDs-were not taken into fully consideration by intelligence. During the Cold War, WMDs were the last choice of both sides, while today, as the NSS points out, "our enemies see weapons of mass destruction as weapons of choice" (p. 15). In an address to the Central European Counterterrorism conference in November 2002, the President said: "[The terrorists] are seeking chemical, biological, and nuclear weapons. Given the means, our enemies would be a threat to every nation and eventually to civilization

11 The speeches considered to constitute the core of the Bush Doctrine were pronounced by the President before the Joint Session of Congress (September 20, 2001) and the Warsaw Conference on Combating Terrorism (November 6, 2001); his State of the Union Address (January 29, 2002); his addresses to the student body of the Virginia Military Institute (April 17, 2002) and to the graduate class at the US Military Academy at West Point (June 1, 2002); his Addresses to the Nation on Iraq, Cincinnati, Ohio, on October 7, 2002 and on March 17, 2003; and his State of the Union on January 28, 2003. 
itself." In his State of the Union Address, in January 2003, the President reinforced this idea: "[...] [T] he gravest danger in the War on Terror, the gravest danger facing America and the world, is outlaw regimes that seek and possess nuclear, chemical, and biological weapons... This threat is new."

We can identify four major tenets in the Bush Doctrine: preemption, unilateralism, military supremacy and the exporting of democracy. The first three pillars are directly linked to American security and the new terrorist threat. The fourth one is crucial for the understanding of the normative conception of the Bush Doctrine. Indeed, it explicitly brings the liberal values to the doctrine and associates them to American national interests. As a matter of fact, as it will be seen below, the commitment with liberalism is present in the Bush Doctrine since its foreword.

As containment and deterrence would not work against this new threat, an element of preemption was to be added to the defense strategy:

Given the goals of rogue states and terrorists, the United States can no longer solely rely on a reactive posture as we have in the past. The inability to deter a potential attacker, the immediacy of today's threats, and the magnitude of potential harm that could be caused by our adversaries' choice of weapons, do not permit that option. We cannot let our enemies strike first... As was demonstrated by the losses on September 11, 2001, mass civilian casualties is the specific objective of terrorists and these losses would be exponentially more severe if terrorists acquired and used weapons of mass destruction... To forestall or prevent such hostile acts by our adversaries, the United States will, if necessary, act preemptively. (NSS 2002, 15).

The National Security Strategy also included unilateral action if necessary. For sure multilateral action was considered: "The United States will constantly strive to enlist the support of the international community" (p. 6). However, multilateralism, which eventually assumed the form of a "coalition of the willing," was not really a prerequisite of the doctrine. Actually, the American government was determined to act unilaterally whenever necessary: "[...] some governments will be timid in the face of terror. And make no mistake about it: if they do not act, America will... And all nations should know: America will do what is necessary to ensure our Nation's security." (The State of the Union, January 29, 2002). One year later, short before the Iraq invasion, the President reassured unilateralism:

All free nations have a stake in preventing sudden and catastrophic attacks. And we're asking them to join us, and many are doing so. Yet the course of this Nation does not depend on the decisions of others. Whatever action is required, whenever action is necessary, I will defend the freedom and security of the American people. (The State of the Union, January 28, 2003). 
To accomplish preemption and unilateralism, American supremacy should be established beyond any doubts. No universal norms or international rules should equally apply to America and the other nations (see Jervis 2003 on this respect). Bush was very clear in his remarks to the graduates of West Point: "America has, and intends to keep, military strengths beyond challenge, thereby making the destabilizing arms races of other eras pointless, and limiting rivalries to trade and other pursuits of peace" (Remarks to the US Military Academy at West Point, June 1, 2002). In fact, the military spending increased dramatically, going from US\$ 290.6 billion in the year 2000, increasing to US\$ 308.5 billion in the year of the terrorist attacks, and jumping to US\$ 606.5 billion in 2008, the last year of Bush's administration (National Defense Budget Estimates for Fiscal Years 2000-2008). Reinforcing American military hegemony became necessary to put into work a foreign policy doctrine based on unilateral preemptive action.

The Bush Doctrine pointed finally to the ultimate and definitive solution to terrorism and tyranny: democracy. The principles and values of liberal democracy, as described by Castro Santos (2010a) for the post-Cold War foreign policy doctrines, were not seen as ideals, but as effective and pragmatic tools against those threats. Even if embodied in a most radical strategy — preemptive unilateral war-, the American Liberal tradition (Hartz 1955) once more prevailed:

In pursuit of our goals, our first imperative is to clarify what we stand for: the United States must defend liberty and justice because these principles are right and true for all people everywhere. [...] America must stand firmly for the nonnegotiable demands of human dignity: the rule of law; limits on the absolute power of the state; free speech; freedom of worship; equal justice; respect for women; religious and ethnic tolerance; and respect for private property. (NSS 2002, 3).

The other speeches that form the core of the Bush Doctrine equally express its commitment to liberalism and the mission to defend it around the world. In his address to Congress, right after the terrorist attacks, Bush said: "Tonight, we are a country awakened to danger called to defend freedom" (September 20, 2001). America "will uphold our duty to defend freedom" (Remarks at the Virginia Military Institute, Lexington, April 17, 2002), "will lift this dark threat from our country and from the world" (Commencement Address at the United States Military Academy in West Point, New York, June 1. 2002), and with its allies will "accept that responsibility" (Address to the Nation on Iraq, March 17, 2003). As a messenger from God, the President explained: "The liberty we prize is not America's gift to the world, it is God's gift to humanity" (State of the Union, January 28, 2003).

The United States national security would be guaranteed by the union of values and interests: 
The US national security strategy will be based on a distinctly American internationalism that reflects the union of our values and our national interests. The aim of this strategy is to help make the world not just safer but better. (NSS 2002, 1).

This conception was repeatedly expressed in the communications of Bush and his Secretaries, as already indicated in the analysis above of the here called third principle.

This direct connection established by the government between promoting democracy and assuring American national interests became indispensable to justify his security-policy doctrine in general, and the Iraq war in particular. Exporting democracy to the rogue states was the definitive solution to every identifiable threat (terrorism, weapons of mass destruction, tyranny). This last element of the Bush Doctrine is precisely what we called here the third principle of the post-Cold War foreign policy doctrine, by which democratic values and national interests go hand in hand. ${ }^{12}$

Concluding this section, it is safe to say, from the findings above, that if unilateral preemptive war was the aggressive response to terrorism, the exporting of democracy by the use of force to the rogue states completed the Bush Doctrine by offering the ultimate weapon to defeat the new threat. The here called third principle played then a crucial role in Bush's foreign and defense policies. In fact, the two policies merged by the tight association between American values and interests.

\section{Motives and justifications for the military interventions in Afghanistan and Iraq}

In this section our task is to demonstrate that although other short-run motives and justifications for the invasions in Afghanistan and Iraq existed and even prevailed over democracy during Bush's first term in office, the building of a democratic system of values and principles in the target countries was the normative element which completed the Bush Doctrine, increasing significantly in the President's second term in office.

The quantitative analysis of 391 speeches by Bush and his Secretaries of State and Defense ${ }^{13}$ counted 381 indications of motives and justifications for the interventions in Afghanistan and Iraq, which were grouped in the following categories: terrorism, rogue states behavior, existence of WMDs, humanitarian assistance, promotion of regional stability, unilateral enforcement of international enactments, democracy, and security.

12 Please refer to the analysis of the role of the third principle above.

13 See footnote 5 for an indication of the speeches analyzed. 
The motives and justifications were assembled in clusters, so to speak, so that they become more meaningful in analytical terms. In this way, we divided them in two broad clusters: the broad security cluster and the broad democracy cluster. This is because we found two basic wide-ranging justifications for Iraq and Afghanistan interventions: the motives and justifications that called on pure security reasons and the motives and justifications that linked democracy to security.

The first cluster of motives and justifications - the security cluster-indicates that the invasion of Afghanistan and Iraq had the purpose of fighting terrorism in these countries because their autocratic regimes were supposed to harbor terrorists, specifically $\mathrm{Al}$ Qaeda, and to produce and distribute WMDs to them. This dreadful combination threatens the security of the United States. The elements of this cluster-terrorism, WMDs and rogue states - appear alone, together or in different combinations two by two in the analyzed speeches. A so-to-speak broad security cluster includes combinations of the narrower security cluster, as just described, with the combination of the three following motivations and justifications, together, two by two or one by one: humanitarian assistance, regional stability, and international law enforcement.

The second cluster of motives and justifications - the democracy clusterpoints to the liberal consideration that only democracy can definitely fight terrorism in the long run. Indeed, it is believed that democracies, by their inherent characteristics of transparency and accountability, do not provide safe haven for terrorists nor distribute WMDs to them. This cluster then brings the democratic motivation alone or in combination with the security cluster. It can also combine with regional stability, humanitarian assistance, and international law enforcement in different ways to form a broad democracy cluster just like described above for the broad security cluster.

More rarely, the promotion of regional stability—which would be brought by the defeat of terrorists and/or by turning the Middle East democratic-, or humanitarian assistance-so much deserved by the Afghans and the Iraqis-, were used alone by the Bush Administration to justify the military invasions to Iraq and Afghanistan. The enforcement of international law to which Saddam Hussein never complied with never appeared alone, but always combined with the security and the democracy clusters, especially with the former in the eve of Iraq's invasion.

In the Bush government, from a total of 381 motives and justifications identified for the invasions of Afghanistan and Iraq in 391 speeches, 65\% referred to the broad security cluster, while the broad democracy cluster reached $30 \%$ (see Table 3). At first sight, therefore, it appears that security took unquestionable precedence over democracy in Bush's foreign and defense policies. The separate exam of his first and second terms, however, better qualifies this result. 


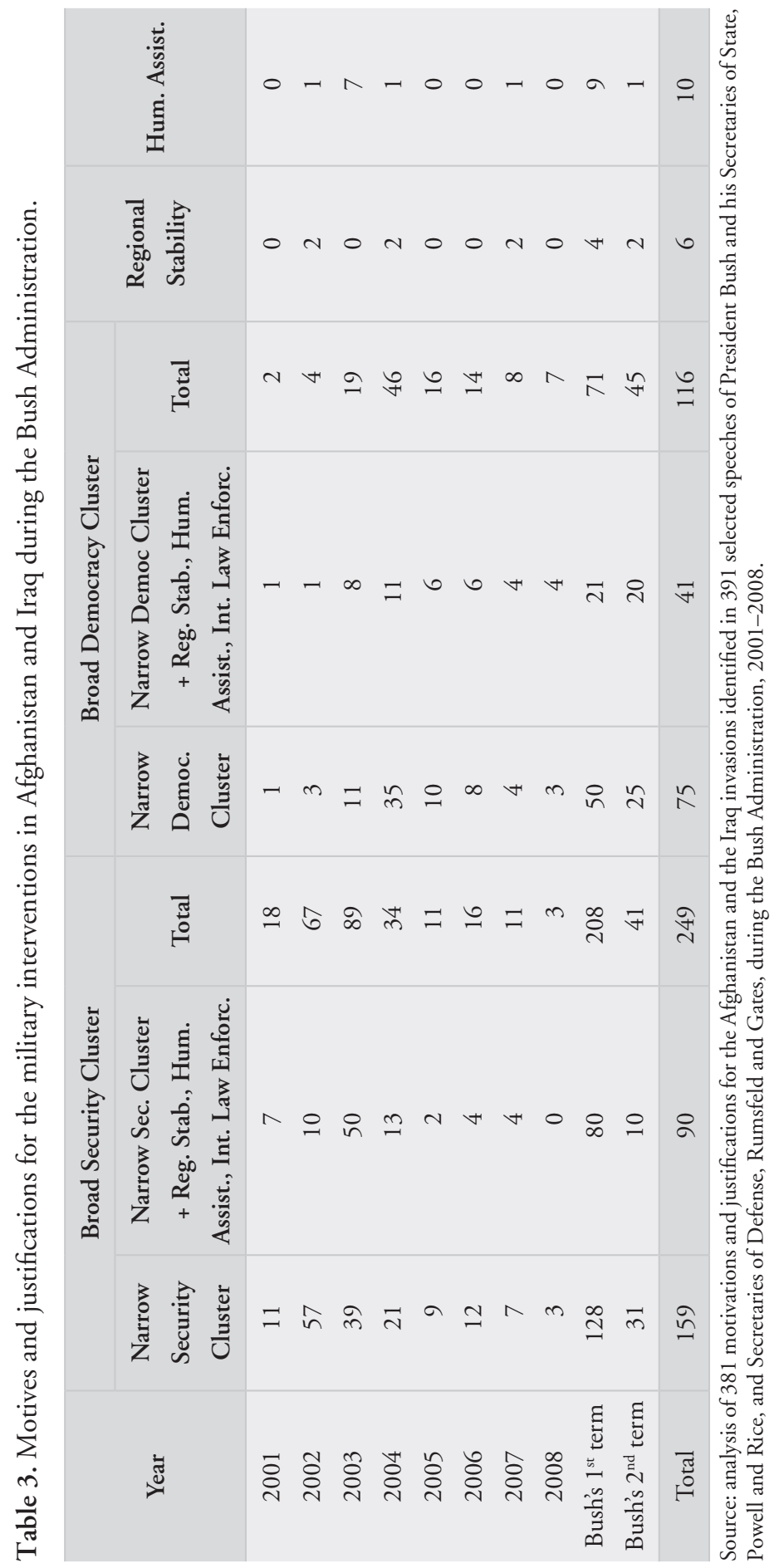


The first Bush Administration faced the Afghanistan invasion, the preparation for the invasion of Iraq, the invasion of Iraq itself, and the occupation of both countries. From a total of 292 motives and justifications identified for such actions in 253 speeches, $44 \%$ referred to different combinations of terrorism, rogue states, and WMDs (the narrow security cluster), while only $17 \%$ related these elements to democracy as their antidote (the narrow democracy cluster).

When one considers the broad clusters, i.e. when regional stability, humanitarian assistance, or the enforcement of international law are taken into account, the difference between the proportions of justifications related to security and democracy enlarges much more: $72 \%$ for the broad security cluster and $24 \%$ for the broad democracy cluster (cf. Table 3 ). This result is due to the large share of justifications for Iraq invasion based on the noncompliance of Saddam Hussein with international law. Indeed, as it will be seen in Figure 2, especially Colin Powell delivered a significant number of speeches indicating how dangerous Saddam Hussein was to the United States and the international community by not complying with uncountable UN Resolutions. In fact, almost 16\% of the 292 motives identified in the decision-makers' speeches in the first Bush Administration referred to this fact. This proportion rises to almost 23\% if we consider the 208 justifications only related to security in Bush's first term in office.

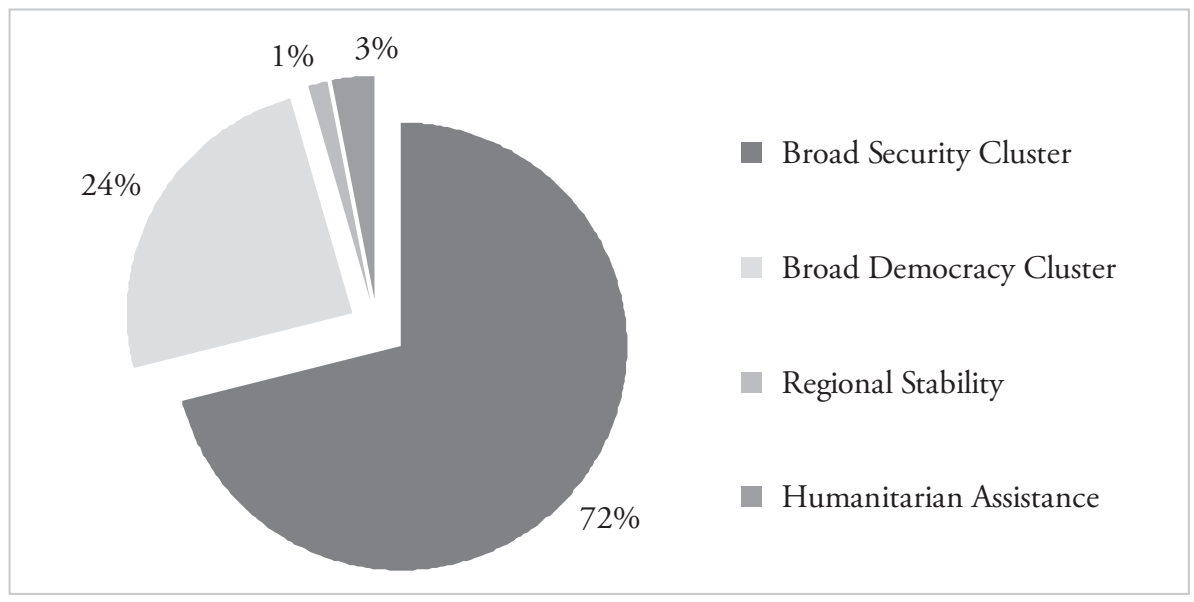

Figure 2. Motives and justifications for the military interventions in Afghanistan and Iraq during Bush's first term.

Source: analysis of 292 motivations and justifications for the Afghanistan and the Iraq invasions identified in 253 selected speeches of President Bush and his Secretary of State, Powell, and Secretary of Defense, Rumsfeld, during the first Bush Administration, 2001-2004.

When Bush inaugurated his second period in office, in 2005, the existence of WMDs in Iraq had already been proved misleading. We analyzed 138 speeches of Bush and his Secretaries of State and Defense, there identifying 79 references 
to justifications and motives to invade Afghanistan and Iraq. In this period, the proportion of the narrow democracy cluster among the whole set of reasons identified in the analysis almost doubled, going from $17 \%$ in the first Bush term to $32 \%$ in his second administration. The narrow security cluster went down: from $44 \%$ to $39 \%$ (cf. Table 3 and Figure 3 ).

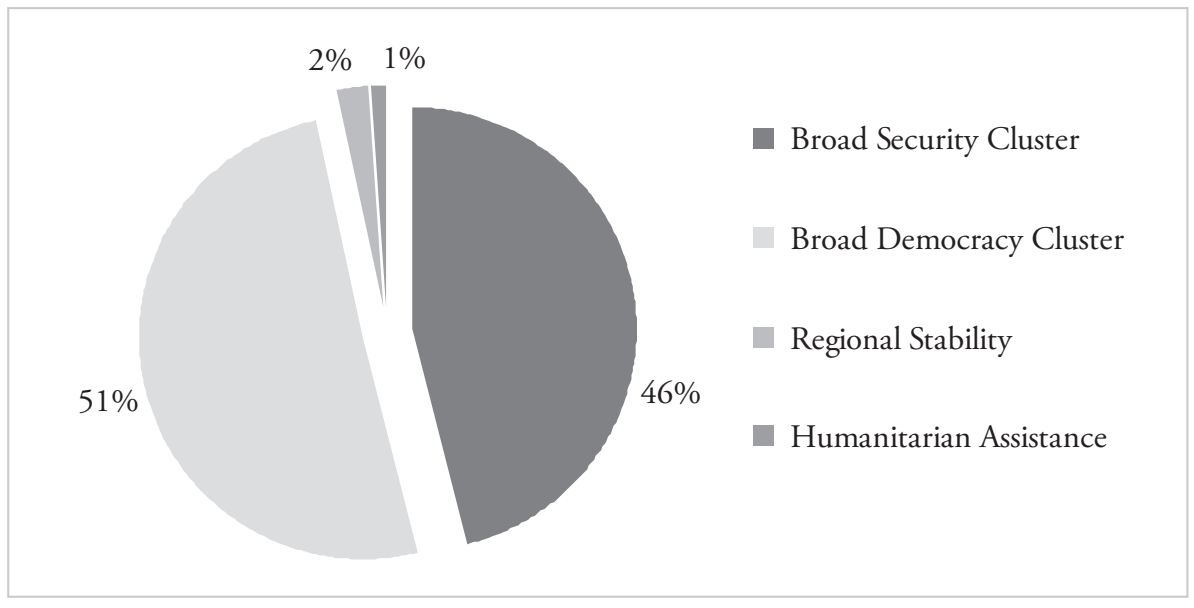

Figure 3. Motives and justifications for the military interventions in Afghanistan and Iraq during Bush's second term.

Source: analysis of 79 motivations and justifications for the Afghanistan and the Iraq invasions identified in 138 selected speeches of President Bush and his Secretary of State, Rice, and Secretaries of Defense, Rumsfeld and Gate, during the second Bush Administration, 2005-2008.

The decrease of the motivations to invade the two rogue states related to security was significant when we examined the broad security cluster: it went down from a proportion of $72 \%$ in the first Bush term to $46 \%$ in the second one. Again the explanation is in the large share of justifications to invade Iraq based on international law enforcement to make Saddam accountable to the world community, which went down almost to zero in the second term of Bush in office. The share of the motivations in the broad democracy cluster went in the opposite direction: it rose significantly, going up from $24 \%$ in the first Bush term to $51 \%$ in his second term. The share of democracy reasons vis-à-vis security justifications for the Iraq and Afghanistan wars did not differ significantly, however, in the second Bush Administration: $51 \%$ and $46 \%$, respectively.

All in all, no matter if we consider the broad or the narrower clusters, the tendency is clear: in the second Bush Administration motivations and justifications to invade Afghanistan and Iraq related to security went down, while those that connected democracy to the other motives and justifications went up. Although concerns about security in itself guaranteed almost half of the total reasons identified in the analysis, these results unequivocally signal the grown importance 
of democracy as the best antidote to the ideology of hatred as prescribed in the Bush Doctrine and relentlessly stated by Condoleezza Rice.

Finally, it is worth pointing that there is a great difference in absolute numbers of motives and justifications for the use of force in the two rogue states from one term of the Bush government to the other. In fact, either considering the broad or the narrower clusters, linked to democracy or security, the total number of motives and justifications for the invasions went down $73 \%$, from 292 in the first term to 79 in the second one. This is not surprising, since the first period was characterized by the beginning of two wars and the government needed to convince the American people that it was acting on behalf of their interests and benefit.

It follows a qualitative analysis of the motives and justifications of the invasions of Iraq and Afghanistan, through the examination of Bush's and his Secretaries of State and Defense's speeches.

The qualitative analysis of the democracy cluster, which encompasses the democratic motivation alone or in combination with security justifications, was already taken care of in the previous analysis of the references to the here called first principle - universality of democratic values—, second principle — democracies do not fight each other, bringing peace and security to the world-, third principledemocracy makes the world safer and more prosperous to the US-, and the American mission - to bring freedom and democracy to mankind-included in the speeches of foreign and defense policies' decision-makers. We will, therefore, concentrate upon the qualitative examination of the security cluster.

Security was the main concern in the first months after the terrorist attacks. The target was Afghanistan, where Al Qaeda supposedly enjoyed a "safe haven":

On my orders, the United States military has begun strikes against Al Qaeda terrorist training camps and military installations of the Taliban regime in Afghanistan. These carefully targeted actions are designed to disrupt the use of Afghanistan as a terrorist base of operations and to attack the military capability of the Taliban regime. (George W. Bush, Address to the Nation, October 7, 2001).

If support for the military operations in Afghanistan were a tacit consensus in the international community, this was not the case for Iraq. A strategy had to be prepared, and soon after the invasion of Afghanistan the focus of the Bush Administration turned to Iraq.

"The threat comes from Iraq," Bush stated in his Address to the Nation on Iraq in October 7, 2002. Along the year of 2002 and the beginning of 2003 Bush dedicated himself to sort of preparing the American people for the next invasion in another dangerous rogue state. He would deliver several Addresses to the Nation on Iraq, where he assured that Saddam Hussein not only gave support and shelter to terrorists but also possessed and produced WMDs. He insisted 
that Saddam's regime had violated all of its obligations before the international community since the Gulf War, had defied the United Nations Security Council resolutions demanding full disarmament, had threatened UN nuclear inspectors, and had continued to threaten the world and the United States (cf. Addresses to the Nation on Iraq in October 7, 2002; February 1, 2003; March 17, 2003; May 1, 2003). The State of the Union speeches of 2002 and 2003 also denounced the danger represented by Iraq to America. These arguments were essentially drawn from security concerns.

The United States pressed very hard the United Nations and its Security Council to react against the "despicable and dangerous" acts of Saddam Hussein. Secretary Powell followed closely the UN resolutions on that matter, demanding a preemptive collective action:

Iraq has now placed itself in danger of the serious consequences called for in UN Resolution 1441. And this body places itself in danger of irrelevance if it allows Iraq to continue to defy its will without responding effectively and immediately. [...] My colleagues, we have an obligation to our citizens. We have an obligation to this body to see that our resolutions are complied with. We wrote 1441 not in order to go to war. We wrote 1441 to try to preserve the peace. We wrote 1441 to give Iraq one last chance. Iraq is not, so far, taking that one last chance. (Colin Powell, Remarks at the UN after Liberian Donors Conference, February 5, 2003).

The same message was repeated a few days after to the Congress (cf. Colin Powell, Testimony before the House Budget Committee, February 13, 2003). Powell stated very clearly since the beginning that the US would act alone if necessary:

[...] if the United States feels strongly that Iraq still has weapons of mass destruction and is trying to develop new ones, the United States reserves the right and believes there is sufficient authority within international law, based on many acts of noncompliance, many material breaches in the past and continuing material breaches into the present, that would give us a basis for undertaking whatever might be required to disarm Iraq. (Colin Powell, Released by the Office of the Spokesman, January 16, 2003).

After the Iraqi invasion Powell still referred to the American unilateral action:

We took the case to the international community, to the United Nations, reminded the world of all the resolutions this individual had violated—Saddam Hussein. And it was time to act. Act we did. He is gone and the people of Iraq are free. (Colin Powell, Washington DC, February 3, 2004).

Unilateral action, if necessary and preemptive war were crucial elements of the Bush Doctrine. They were used promptly and unambiguously when it came 
to the invasion of Iraq. In this moment, the existence of WMDs and the fear that they could end in terrorists' hands were justifications for military actions very much enforced. Secretary of Defense Rumsfeld did it the most, especially along the preparation of the invasion. He emphasized the links between terrorists and rogue states that have WMDs:

The real concern at the present time is the nexus between terrorist networks and terrorist states that have weapons of mass destruction. And let there be no doubt, there is that nexus, and it must force people all across this globe to realize that what we're dealing with here is something that is totally different than existed in previous periods, and it poses risks of not thousands of lives, but hundreds of thousands of lives, when one thinks of the power and lethality of those weapons. (Donald Rumsfeld, $21^{\text {st }}$ Century Transformation of US Armed Forces, January 31, 2002).

Some have argued that Iraq is unlikely to use weapons of mass destruction against us because, unlike terrorist networks, Saddam Hussein has a return address; that is to say he's probably deterrable, is the argument. Well, Mr. Chairman, there's no reason for confidence that if Iraq launched a WMD attack on the US that it would necessarily have an obvious return of address. There are ways Iraq can easily conceal responsibility for a WMD attack. For example, they could give biological weapons to terrorist networks to attack the United States from within and then deny any knowledge. Suicide bombers are not deterrable. (Testimony of US Secretary of Defense Donald H. Rumsfeld before the House Armed Services Committee regarding Iraq, September 18, 2002).

Other Rumsfeld typical messages on the subject were delivered to the Armed Forces (Meeting with Troops, April 26, 2002) and to the Senate (Testimony before the Senate Armed Services Committee regarding Iraq, September 19, 2002).

When it became clear that the WMDs did not exist, Bush, Powell, and Rumsfeld came forward insisting that given the "solid intelligence base" of the information upon which they rested their decisions, Saddam's poor records and the dictator's refusal to open the country to international inspection, the invasion of Iraq was right. On this matter, Bush said:

From this office, nearly 3 years ago, I announced the start of military operations in Iraq. Our coalition confronted a regime that defied United Nations Security Council resolutions, violated a ceasefire agreement, sponsored terrorism, and possessed, we believed, weapons of mass destruction. After the swift fall of Baghdad, we found mass graves filled by a dictator. We found some capacity to restart programs to produce weapons of mass destruction, but we did not find those weapons. It is true that Saddam Hussein had a history of pursuing and using weapons of mass destruction. (George W. Bush, Address to the Nation on Iraq and the War on Terror, December 18, 2005). 
It is worth noting as well Colin Powell's remarks at UN (After Liberian Donors Conference, February 6, 2004) and Donald Rumsfeld's Remarks to the Heritage Foundation (May 17, 2004) about the WMDs issue.

When Condoleezza Rice and Robert Gates became, respectively, the Secretary of State (January 2005) and the Secretary of Defense (December 2006) in the second term of the Bush Administration, WMDs were no longer the American concern in Iraq, nor were they impelled to defend the preemptive war strategy. They were focused on winning the War on Terror and this meant not only a definitive victory in the battlefield, but also and above all the building of democracy in the target states. At this point, justifications for the invasions based on democracy went up extraordinarily as pointed above.

All in all, we can say that the security concerns in themselves were the main motivations to the invasions in Iraq and Afghanistan, although the building of democracy in these countries was significantly referred to since the early hours after the terrorist attacks. However, it is very important to notice that after the existence of WMDs in Iraq was proved false, the decrease of the justifications to the invasions based on security in itself, even if combined with other motives, strongly decreased while those based on democracy as the final weapon to beat terrorism went up remarkably as well.

\section{Conclusions}

The content analysis of the 391 speeches from President Bush, Secretaries of State Colin Powell and Condoleezza Rice, and Secretaries of Defense Donald Rumsfeld and Robert Gates, indicates that the American foreign policy after September 11,2001, is deeply embedded in the values of freedom and liberalism, even if translated in the radical terms of the Bush Doctrine. The liberal tradition is responsible for the belief in the universality of the democratic values, in the direct relation established between democracy and security, and in the active defense of the American mission.

The missionary task, identified since the founding fathers and clearly incorporated by the Bush Administration, is based on the premise that the US is the political Messiah of the world. American intentions are benign and attempt not to dominate, but to liberate. Certainly there is a glorification of the American exceptionalism and its political blessings - the creation of a political system that is both free and stable-believed to impose to the American people and their decision-makers' responsibilities before the rest of the world. The liberal tradition grants the US the role of an exceptional nation and of a unique country, and to Americans the status of a chosen people. Moreover, when Americans say that democracy promotion is a responsibility to be accepted, a burden to be carried on, a sacrifice to be made, a call from history or from God, or yet a manifest destiny, the missionary rhetoric shapes the alternatives of action and makes the eventual 
intervention a moral legitimate imperative, even if preemptive, even if unilateral, even if by the use of force.

Because US liberal values are right and true, they are believed to be universal and desired by all the people in the world. That is the conviction of the American people, their decision-makers and a great part of the scholars. When the United States invaded Afghanistan and Iraq, they were not only accomplishing their noble and almost religious mission, but also helping the people of those countries. American soldiers should then be received as liberating heroes. This is Bush's application of the here called first principle and the American mission, tenets of the US foreign policy in the post-Cold War age.

The American liberal tradition also meets the Kantian peace and establishes a bridge, so to call, with regional and international security. Since democracies are less likely to wage war against each other, the US acts in the name of world peace. A second order effect is that a democratic Iraq would spread democracy through the Middle East, bringing at last peace and security to this troubled region. This is the here called second principle of the American foreign policy doctrine after the Cold War.

Finally, the American liberal tradition is embedded in the principle which completes the doctrine of the US foreign policy in the post-Cold War period. The here called third principle bonds liberal values with American national interests. It is an explicit call for the most conservative Americans, showing that the foreign policy doctrine is not entirely altruistic. International threats like terrorism and WMDs are linked to authoritarian regimes and justify the use of force to promote regime change. Bush really seemed to believe in the efficacy of exporting democracy abroad resorting to American military power. Democracy would make the United States and the world not only safer but better.

In so far as these liberal ideas represented the dominant view in Bush's foreign policy team after the terrorist attacks, US national security strategy forged a radical interventionist defense policy which fostered as well the exporting of liberal democracy to strategic countries. This defense doctrine was founded in preemption, unilateralism and American supremacy, but it was only completed when the third principle of the foreign policy above mentioned assumed its role. Liberalism in the National Security Strategy is clear since its foreword: " $\mathrm{t}] \mathrm{he}$ great struggles of the twentieth century between liberty and totalitarianism ended with a decisive victory for the forces of freedom - and a single sustainable model for national success: freedom, democracy and free enterprise." The exporting of these values, even if by the use of force, which are not only American but also universal, would guarantee the US national interests, there included security and economic interests.

It is clear then that, in the Bush Administration, values and interests merge, as merge its foreign and defense policies. However, it is important to say that the justifications for the invasions of Iraq and Afghanistan were based primarily on 
security concerns - the annihilation of Al Qaeda, the dismantling of all terrorist camps, the ousting of Saddam Hussein, the neutralization of WMDs_-during the first years of the terrorist attacks. This is not surprising after September 11's tragic blow. Notwithstanding, democracy building in the target states was a justification for the invasions since the beginning. But it was only in Bush's second term, when the existence of WMDs in Iraq was proved wrong, that decision-makers resorted remarkably to democratization of the hostile countries as a guarantee of American security and national interests, surpassing reasons invoked in the name of pure security.

Finally, it is important to remember that the craft of democracy is no easy task. Letting aside the human and financial costs of the wars, according to Freedom House, Iraq and Afghanistan have made very subtle democratic improvements, both changing their ratings from 7.0 (the most oppressive) before the interventions to 6.0 (still not free at all). This fact should raise questions about the worthiness of democracy promotion or, at least, about the efficacy of a foreign intervention to impose a regime change without taking into consideration internal variables like the level of economic development or the historical, cultural and religious cleavages. These concerns will be taken into consideration in another communication.

\section{Bibliographic references}

Boorstin, Daniel J. (1953). The Genius of American Politics. Chicago: University of Chicago Press.

Buzan, Barry (2004). The United States and the Great Powers: World Politics in the Twenty-First Century. Cambridge, UK: Polity Press.

Castro Santos, Maria Helena and Teixeira, Ulysses Tavares (2012), The Essential Role of Democracy in the Bush Doctrine. Presented to the International Studies Association Annual Convention 2012: Power, Principles and Participation in the Global Information Age, 2012, San Diego, CA. ISA Annual Convention Paper Archive, 2012.

Castro Santos, Maria Helena (2010a). Exportação de Democracia na Política Externa NorteAmericana no Pós-Guerra Fria: Doutrinas e o Uso da Força. Revista Brasileira de Política Internacional, Ano 53, no 1, 2010, p. 157-191.

(2010b), O Processo de Democratização da Terceira Onda de Democracia: quanto pesam as variáveis externas? Published at Meridiano 47. Available at: <http://merediano47.info/2010/02>.

(2010c), Opapel dos Estados Unidos na nova ordem internacional e as intervençöes militares americanas no pós-Guerra Fria: que lugar ocupa ai a democracia? Published at Meridiano 47. Available at: <http://merediano47.info/2010/02>.

Department of Defense (2000-2008). National Defense Budget Estimates for Fiscal Years 2000-2008, Office of the Under Secretary of Defense (COMPTROLLER), available at: $<$ comptroller.defense.gov/Docs/fy2008_greenbook.pdfß .

Diamond, Larry (1994), The global imperative: Building a democratic world order, Current History, January 1994, volume 93, number 579. 
Farer, Tom (1996). Collectively Defending Democracy in the Western Hemisphere, Introduction and Overview. In Farer, Tom (ed.). Beyond Sovereignty: Collectively Defending Democracy in the Americas. Baltimore and London: The Johns Hopkins Un. Press.

Fukuyama, Francis (1992). The End of the History and the Last Man. New York: Avon Books.

Fukuyama, Francis and Michael McFaul (2007), Should Democracy Be Promoted or Demoted? The Stanley Foundation, June 2007.

Hartz, Louis (1955). The Liberal Tradition in America - an interpretation of American political thought since the revolution. New York: Harcourt, Brace \& World.

Hofstadter, Richard (1948). The American Political Tradition and the Men who Made It. New York: Alfred A. Knopf.

Huntington, Samuel (1996), The Clash of Civilizations and the Remaking of World Order. New York: Simon \& Schuster.

Iraq Survey Group (2004), Comprehensive Report of the Special Advisor to the DCI on Iraq's WMD (Final Report and Addendums to the Report), September, 30, 2004, available at: <https:// www.cia.gov/library/reports/general-reports-1/iraq_wmd_2004/index.html>.

Jervis, Robert (2003). Understanding the Bush Doctrine, Political Science Quarterly, Volume 118, Number 3, 2003.

Lipset, Seymour Martin (1996). American Exceptionalism: A Double-Edged Sword. New York: W.W. Norton.

Owen IV, John M. (2006), Democracy, Realistically, National Interest, Spring 2006, Issue 83.

Packenham, Robert A. (1973). Liberal America and the Third World. New Jersey: Princeton University Press.

Patrick, Stewart (2001), Don't fence me in: the perils of going it alone, World Policy Journal, 18:3 (Fall 2001), p. 2-14.

Pew Research Center. Public Attitudes Toward the War in Iraq: 2003-2008, March 19, 2008. Available at: <http://www.pewresearch.org/2008/03/19/public-attitudes-toward-the-war-iniraq-20032008/>.

Rice, Condoleezza (2000), Promoting the National Interest, Foreign Affairs, 79:1 (January/ February 2000).

(2007). American power: The Hobbled Hegemon. The Economist, Jun 28th 2007.

(2008), Rethinking the National Interest - American Realism for a New World. Foreign Affairs, July/August 2008.

Teixeira, Ulysses Tavares (2010). Tradição Liberal e Exportação de Democracia na Era Bush. (Liberal Tradition and Exporting of Democracy in the Bush Era) Unpublished Master dissertation presented to the Graduate Program in International Relations of the University of Brasilia.

Tocqueville, Alexis de (1987). A Democracia na América. 3. ed. Belo Horizonte, MG: Itatiaia. White House (2002). The National Security Strategy of the United States of America. White House, September 2002. 


\begin{abstract}
Everyone knows that democracy played a role in the Bush Doctrine. What not everyone knows is that this role was essential for the doctrine to be put into operation under which the Iraq invasion was prepared and launched. We argue moreover that, even if aggressive, the Bush doctrine is compatible with the American Liberal Tradition. To demonstrate these arguments we analyze the links between democracy, security, and the US national interests as expressed in the pillars of the American foreign policy since the end of Cold War. The consequential belief of the Bush Administration on the positive effect of exporting democracy by the use of force to Afghanistan and Iraq to fight terrorism will be remarked. It will be shown, however, that in the first years of the Bush Administration, among the justifications for the military interventions in the two countries, security reasons prevailed over democratic concerns, although the latter was significantly present since the early hours after September 11. It was only when it became clear that WMDs did not exist in Iraq that the exporting of democracy as the ultimate weapon to fight terrorism grew remarkably and prevailed over security reasons to invade those rogue states. The paper uses quantitative and qualitative content analysis of the speeches of President Bush and his Secretaries of State and Defense.
\end{abstract}

Keywords: Afghanistan; Bush Doctrine; exporting of democracy; Iraq; military intervention.

\title{
Resumo
}

Todos sabem que a democracia teve um papel importante na Doutrina Bush. O que nem todos sabem é que esse papel foi essencial para que a doutrina pudesse ser posta em operação, sob a qual a invasão do Iraque foi preparada e conduzida. Será argumentado também que, ainda que agressiva, a Doutrina Bush é compatível com a Tradição Liberal americana. Para demonstrar esses argumentos, serão analisados os vínculos entre democracia, segurança e os interesses nacionais americanos, conforme identificados nos pilares da política externa americana desde o fim da Guerra Fria. A crença da administração Bush nos efeitos positivos da exportação de democracia pela força para o Afeganistão e para o Iraque no combate ao terrorismo será destacada. Será mostrado, contudo, que entre as justificativas e motivações para as intervenções militares nos dois países, as razões de segurança prevaleceram sobre preocupações democráticas, embora esta última esteja significativamente presente desde as primeiras horas após o 11 de setembro. Depois que se tornou claro, no entanto, que as armas de destruição em massa não existiam no Iraque, a exportação de democracia como arma definitiva de combate ao terrorismo cresceu significativamente como justificativa para as invasões dos rogue states e se sobrepôs às motivações de segurança. O artigo usa a análise de conteúdo qualitativa e quantitativa dos discursos do Presidente Bush e de seus Secretários de Estado e Defesa.

Palavras-chave: Afeganistão; doutrina Bush; exportação de democracia; Iraque; intervenção militar. 